in vivo $35: 713-719(2021)$

doi:10.21873/invivo.12312

\title{
Variation of BMP2 Concentration and Its Activity in Bone Grafts Obtained from Patients Undergoing Hip Replacement Surgery
}

\author{
ALEXANDER WURM ${ }^{1}$, DIETMAR DAMMERER ${ }^{1}$, MICHAEL CHRISTIAN LIEBENSTEINER ${ }^{1}$, \\ MICHAEL NOGLER ${ }^{2}$, CHRISTOPH AMMANN $^{2}$ and DÉBORA CORAÇA-HUBER ${ }^{2}$ \\ ${ }^{1}$ Department of Orthopaedics and Traumatology, Medical University of Innsbruck, Innsbruck, Austria; \\ ${ }^{2}$ Department of Experimental Orthopaedics, Medical University of Innsbruck, Innsbruck, Austria
}

\begin{abstract}
Aim: Bone morphogenetic protein 2 (BMP2) is a member of a subgroup of the transforming growth factor beta superfamily and triggers various signaling events which in turn stimulate chondrogenesis, osteogenesis, angiogenesis and extracellular matrix remodeling leading to fracture healing. In this study, we quantified the concentration of BMP2 in fresh human bone grafts obtained from 40 patients undergoing hip replacement surgery. Besides the concentration, the activity of the detected BMP2 was also investigated. Materials and Methods: In this study, the concentration of BMP2 in fresh human bone grafts obtained from 40 patients undergoing hip replacement surgery was quantified. Human BMP2 enzymelinked immunosorbent assays and bicinchoninic acid quantification was used to determine the total concentration of protein present in each sample. To determine the activity of the BMP2 found in each bone sample, alkaline phosphatase activity was measured by colorimetric assay. Results: The amount of BMP2 seemed to vary slightly between the patients. Taking into consideration the patient's gender, we observed that male patients presented slightly more BMP2 in comparison with females. When analyzing the activity of $B M P 2$, we observed that in female patients, the activity was slightly higher in comparison to males. This variation may be caused by a number of factors, including but not limited to gender, age, osteoporosis and previous diseases. This
\end{abstract}

This article is freely accessible online.

Correspondence to: Associate Professor Dr. Dietmar Dammerer, MD, MSc, Ph.D., Department of Orthopaedics and Traumatology, Medical University of Innsbruck, Anichstrasse 35, 6020 Innsbruck, Austria. Tel: +43 51250422691, e-mail: dietmar.dammerer@tirolkliniken.at

Key Words: BMP2, bone morphogenetic protein 2, TGF $\beta$, bone graft, protein activity. information shows that the osteogenic potential of different bone graft samples is not consistent. Conclusion: The activity of BMP2 in femur heads obtained from patients undergoing total hip replacement surgery showed significant variation according to gender and age. The measurement of bone proteins activity might be promising as a qualitative method in bone banks and should be further investigated.

The use of bone grafts has become well established in orthopedic surgery for reconstructing skeletal defects, after trauma lesions or disease (1-5). Autografts (tissue from the same patient) or allografts (tissue from the same species) can be used for this purpose. Bone grafts have the ability to induce new bone formation and to facilitate new bone formation (6). Several tests are conducted by bone banks to reduce the risk of transmitted diseases through the use of grafts. The following tests are performed by the bone bank of our Institution, according to the Austrian Tissue Safety Law (GSG; acronym in German), the Tissue Bank Act (GBVO, acronym in German) and the Tissue Removal Department Act (GEEVO, acronym in German): Smear tests for fungi, aerobic and anaerobic microbes, long-term incubation and a histological examination. Serological tests include human immunodeficiency virus (HIV) (HIV1/2 antibodies and polymerase chain reaction (PCR), hepatitis A (PCR), hepatitis B virus (HBs antigen, $\mathrm{HBc}$ antibodies, and PCR), hepatitis C virus (antibodies and PCR), Parvovirus B 19 (PCR), Lues- serology (ELISA) and glutamate pyruvate transaminase (GPT). In addition, donors have to complete a specific anamnesis questionnaire (7-9). To date, no tests are carried out by bone banks to detect bone morphogenetic protein (BMP) or the tissue osteogenic capacity $(5,10-12)$.

Osteoblasts and osteoclasts play an important role in the bone remodeling process. The transforming growth factorbeta (TGF $\beta$ ) signaling pathway is part of the cycle involved in their formation and differentiation (13). TGF $\beta$ belongs to a superfamily of over 30 members including three TGF $\beta$ 
isoforms, BMPs, activins, inhibins and müllerian inhibiting substance $(13,14)$. BMPs are released during the bonehealing process, in which they support the ossification process during remodeling of morselized and impacted bone grafts (15-17). BMP2 is a member of a subgroup of the TGF $\beta$ superfamily and triggers various signaling events, which in turn stimulate chondrogenesis, osteogenesis, angiogenesis and extracellular matrix remodeling leading to fracture healing $(18,19)$. BMP2 deficiency has been implicated in delayed union or nonunion, and recombinant BMP2 and BMP7 have been clinically used in the treatment of these conditions (18-21). In addition, the possibility of involvement of a BMP-related genetic predisposition in impaired fracture healing has been reported $(19,22)$.

Besides the importance of quality controls regarding contamination and transmitted diseases, we believe it is also important to conduct a quality test to measure the content of BMPs in bone grafts. This may provide valuable information about the condition of the bone graft samples and their biocompatibility. As BMP2 is indispensable for the initiation of fracture healing $(18,20,22,23)$, the control of BMP2 quantity and quality in bone allografts may be an option for qualitative tests at bone banks. In this study, we quantified the amount of BMP2 in fresh human bone grafts obtained from 40 patients undergoing hip replacement surgery. Besides the amount, the activity of the detected BMP2 was also investigated.

\section{Materials and Methods}

Preparation of bone chips. Femur heads were obtained from 18 male patients and 22 female patients who had undergone total hip replacement surgery (due to arthrosis or femoral neck fracture) at our Department (Table I). All patients previously approved the use of their samples for research purposes. During osteotomy, the bone was flushed and cooled with $0.9 \%$ saline to prevent being damaged by heat. Cartilage and cortical tissues were removed from the femoral heads with a bone saw. Bone chips (BCh; $3-5 \mathrm{~mm}$ diameter) were obtained from the remaining spongious tissue using a bone mill (Noviumagus Bone Mill; Spierings Meische Techniek BV, Nijmegen, the Netherlands). The $\mathrm{BCh}$ were stored at $-20^{\circ} \mathrm{C}$ until the tests were performed.

Total protein extraction from bone samples. From each patient, $1 \mathrm{~g}$ of BCh was prepared as followed: $2.5 \mathrm{ml}$ of phosphate-buffered saline was added to all fresh samples. After vortexing for $1 \mathrm{~min}$ and centrifuging at $1,502 \times g$ for $5 \mathrm{~min}$, three layers were formed: a yellow fat layer on top, a light-red layer in the middle, and a bone layer at the bottom. From the mid layer, $1.2 \mathrm{ml}$ were removed, transferred to tubes and stored at $-20^{\circ} \mathrm{C}$ until the time of the tests $(24,25)$.

Total bone protein quantification. Bicinchoninic Acid Protein Assay Kit (Sigma-Aldrich, Schnelldorf, Germany) was used to determine the total amount of protein present in each sample. The quantification was carried out following the manufacturer's procedures.
Table I. Number, gender and age of the patients included in the study.

\begin{tabular}{lcc}
\hline & \multicolumn{2}{c}{ Gender, $\mathrm{n}$} \\
\cline { 2 - 3 } Age, years & Female & Male \\
\hline$<50$ & 2 & 3 \\
$50-60$ & 6 & 2 \\
$60-70$ & 4 & 5 \\
$>70$ & 10 & 8 \\
Total & 22 & 18 \\
\hline
\end{tabular}

Quantification of BMP2 in bone samples. Human BMP2 ELISA Kit (Sigma-Aldrich, Schnelldorf, Germany) was used to quantify the amount of BMP2 from human femoral bone grafts. All samples were thawed at room temperature and vortexed. From each sample, $100 \mu \mathrm{l}$ was transferred into the wells of the Human BMP2 antibodycoated ELISA plate. Each sample was run in duplicate. The absorbance was measured at $450 \mathrm{~nm}$ on an ELISA microplate reader. The assays were carried out following the manufacturer's protocol (the limit of detection was $3.9 \mathrm{pg} / \mathrm{ml}$ and the limit of quantitation was $27.0 \mathrm{pg} / \mathrm{ml}$ ).

Measurement of activity of BMP2 extracted from bone samples. To determine the activity of the BMP2 found in each bone sample, alkaline phosphatase activity colorimetric assay kit (BioVision Incorporated, Milpitas, CA, USA) was used.

The murine $\mathrm{C} 2 \mathrm{C} 12$ cell line (CRL-1722; Mus musculus; American Type Culture Collection, Manassas, VA, USA) was cultured as recommended by the supplier at $37^{\circ} \mathrm{C}$ and with $10 \%$ $\mathrm{CO}_{2}$. Cells were cultured and expanded in growth media [high glucose DMEM (Corning) supplemented with $10 \%$ fetal bovine serum, $1 \%$ penicillin-streptomycin, and $1 \%$ L-glutamine $(200 \mathrm{mM})]$ and split at 1:10 ratios at $80 \%$ confluence. For the vitality tests, cells were harvested from the main culture by adding $2 \mathrm{ml}$ of Acutase ${ }^{\circledR}$ (Sigma-Aldrich, Schnelldorf, Germany) and the cells were incubated for $5 \mathrm{~min}$ at room temperature. For the preparation of a final solution, $5 \times 10^{4}$ of cells were resuspended into fresh medium.

The cells were then incubated for $60 \mathrm{~min}$ at $25^{\circ} \mathrm{C}$ with each patient's sample $(50 \mu \mathrm{l})$ and afterwards the alkaline phosphatase was measured using the above-mentioned kit. The activity of the BMP2 was measured by colorimetric measurement of each sample. All tests were carried out following the manufacturer's protocol.

Statistical analysis. According to the standard curves for each test, the concentrations were calculated after the regression model using Excel 2010 (Microsoft Corporation, Redmont, Washington, USA). GraphPad Prism (GraphPad Prism 7.00, GraphPad Software, Inc., La Jolla, CA, USA) was used for the statistical analysis and to generate the illustration graphs. The values are reported as mean \pm SEM.

\section{Results}

Quantification of total BMP2 per bone sample. The amount of BMP2 varied between the patients. The average amount of BMP2 detected in the bone allografts was $164.6 \pm 12.39$ 


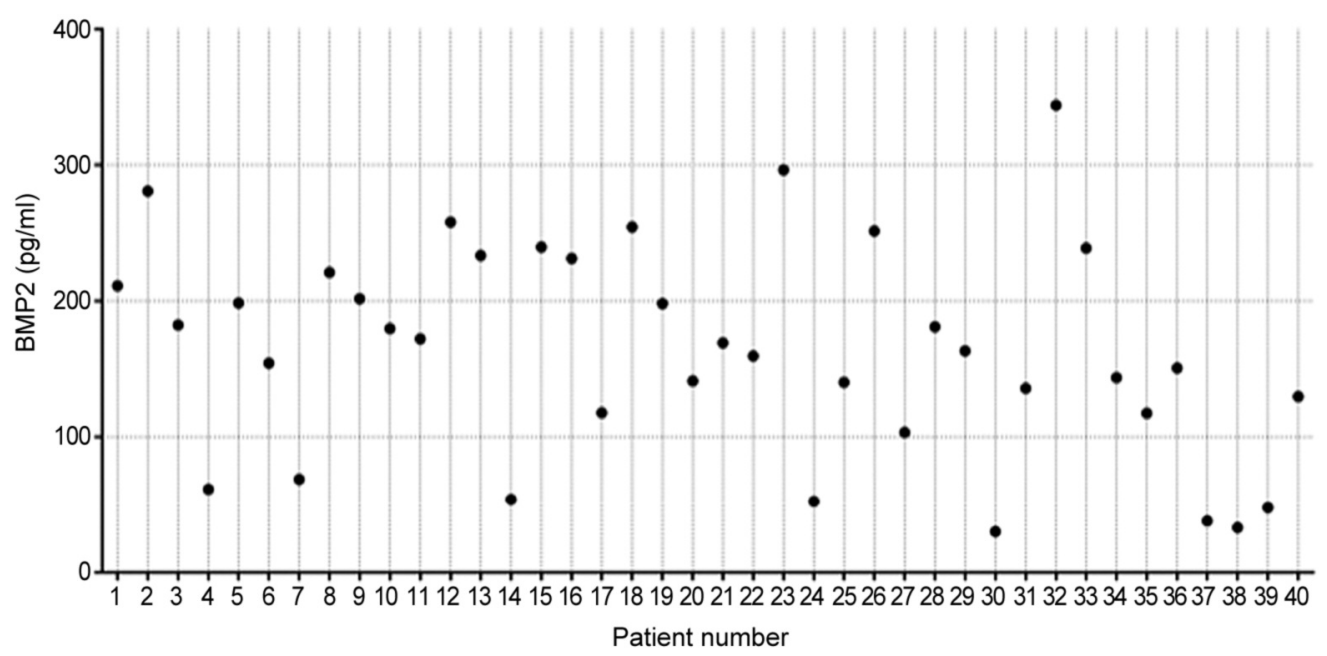

Figure 1. Quantification of bone morphogenetic protein 2 (BMP2) for each patient. The concentration was determined for samples of bone extract according to standard curves.
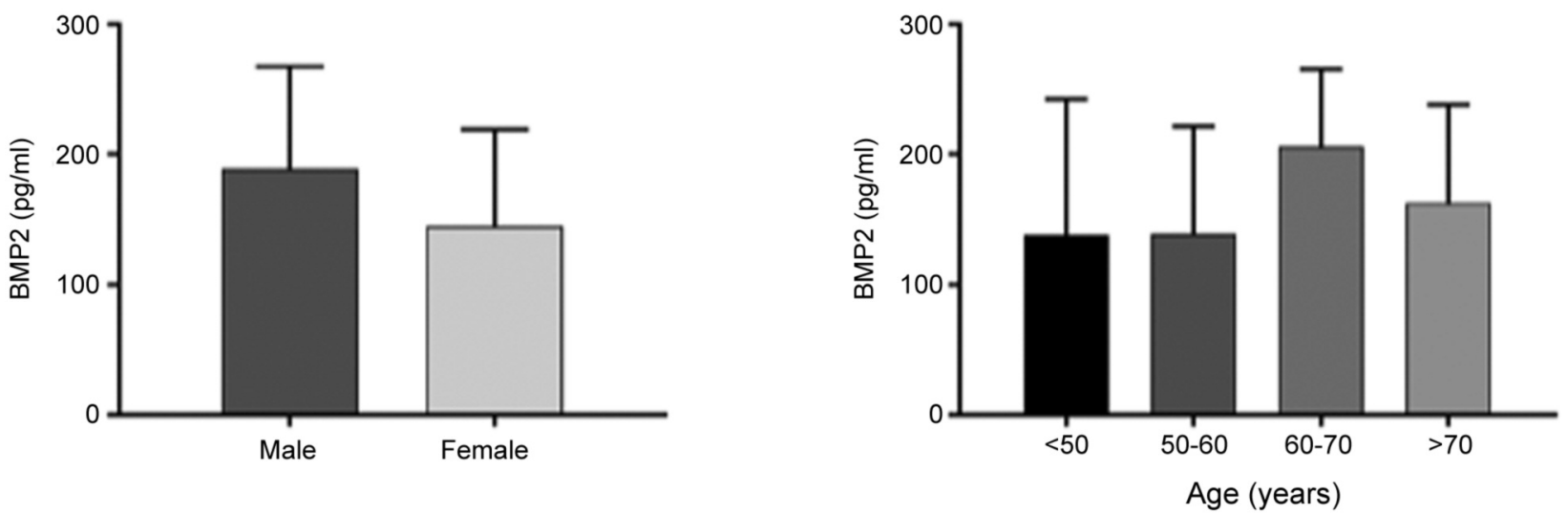

Figure 2. The amount of bone morphogenetic protein 2 (BMP2) in bone samples from male and female patients (A) and in patients of different age groups $(B)$. Data values are reported as the mean \pm SEM.

$\mathrm{pg} / \mathrm{ml}$, showing significant difference between individual patients $(p<0.0001$; Figure 1). Taking into consideration the patient's gender, we observed that male patients presented slightly more BMP2 in comparison with female patients ( $p>0.05$; Figure 2A). Within the age groups, the statistical analysis showed no significant difference in the amount of BMP2 ( $p>0.05$; Figure 2B).

Amount of BMP2 per gram of total protein. We calculated the ratio of BMP2 per gram of total protein detected (BCA test; Figure 3 ). The amount of BMP2 per gram of total protein also varied between the patients, showing similar differences when compared to the total amount of BMP2 (Figure 1). The average amount of BMP2 was $130.4 \pm 13.75$ per gram of total protein and statistical analysis showed significant differences between the patients $(p<0.0001$; Figure 3$)$. Taking into consideration the patient's gender and age we observed similar distributions for the amount of BMP2 related to the amount of total protein (Figure 4A and 4B).

Activity of BMP2 present in patient bone samples. The activity of BMP2 detected in the bone samples significantly varied between the patients $(p<0.0001)$. However, the values remained between 0 and $2 \mathrm{U} / \mathrm{pg}$ of BMP2, showing very high activity only in three samples, namely patients 14, 24 and 30, with values of 2.9, 3.6 and 5.5 U/pg BMP2, respectively (Figure 5). Taking into consideration patient gender, we observed that the activity of BMP2 was slightly higher in female patients in 


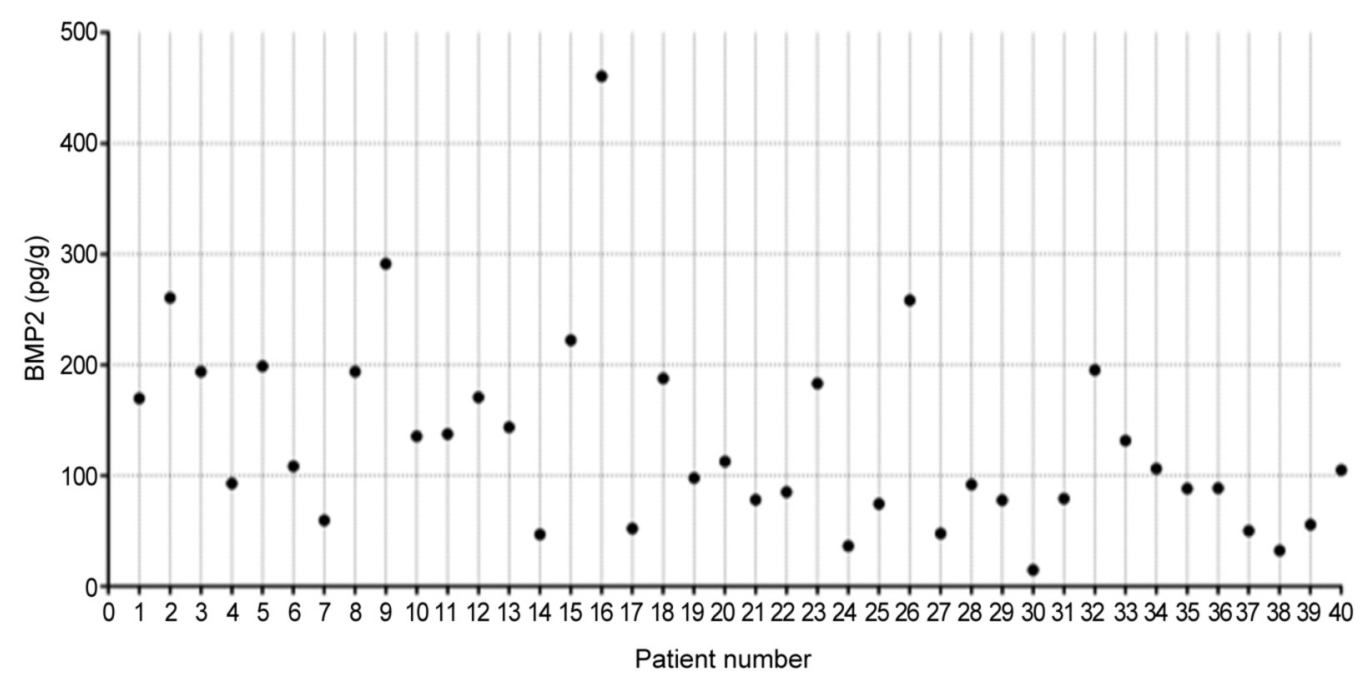

Figure 3. Amount of bone morphogenetic protein 2 (BMP2) per gram of total bone protein found in each bone sample.
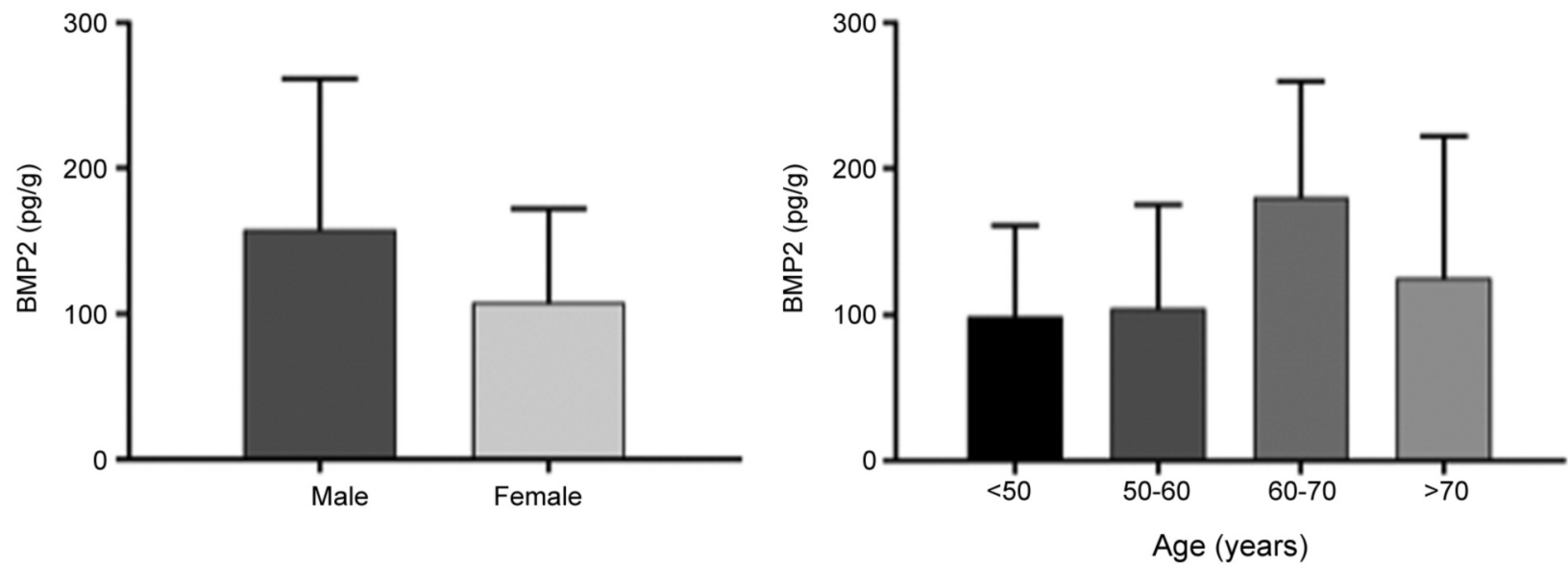

Figure 4. Amount of bone morphogenetic protein 2 (BMP2) per gram of total bone protein by gender (A) and by age (B). Data values are reported as the mean \pm SEM.

comparison to males ( $p>0.05$; Figure $6 \mathrm{~A})$. The values for each age group again showed a different distribution when compared to the values for the amount of BMP2. Highest BMP2 activity was observed in the group of patients aged 5060 years and the lowest in those aged 60-70 years (Figure 6B); the difference here was also not significant $(p>0.05)$.

\section{Discussion}

The amount of BMP2 varied significantly between individual patients $(p<0.0001)$. No bone banks have routinely carried out tests to classify the quality of human bone grafts based on the profile of bone proteins. Measurements of BMPs $(24,26)$ might help to arrange human bone grafts into different levels of quality. In this way, patients with severe health conditions might benefit from bone grafts with a higher amount of active BMPs, offering better chances of bone healing $(19,27,28)$. ELISA tests might be incorporated in the routine for quality control of the bone bank.

The values obtained in this study for the amount of BMP2 from bone grafts are compatible to some studies found in the literature (29). Wildemann et al. quantified BMP2 and other growth factors in bone grafts after different sterilization methods. They detected a maximum of $450 \pm 273$ pg BMP2 per $g$ of total protein after treatment of the bone grafts with guanidine hydrochloride/ethylenediaminetetraacetic acid method. A very low amount of BMP2 was detected by other cleaning methods in comparison: $1.5 \pm 0.7 \mathrm{pg} / \mathrm{g}$ after collagenase, and $1.9 \pm 1.07 \mathrm{pg} / \mathrm{g}$ 


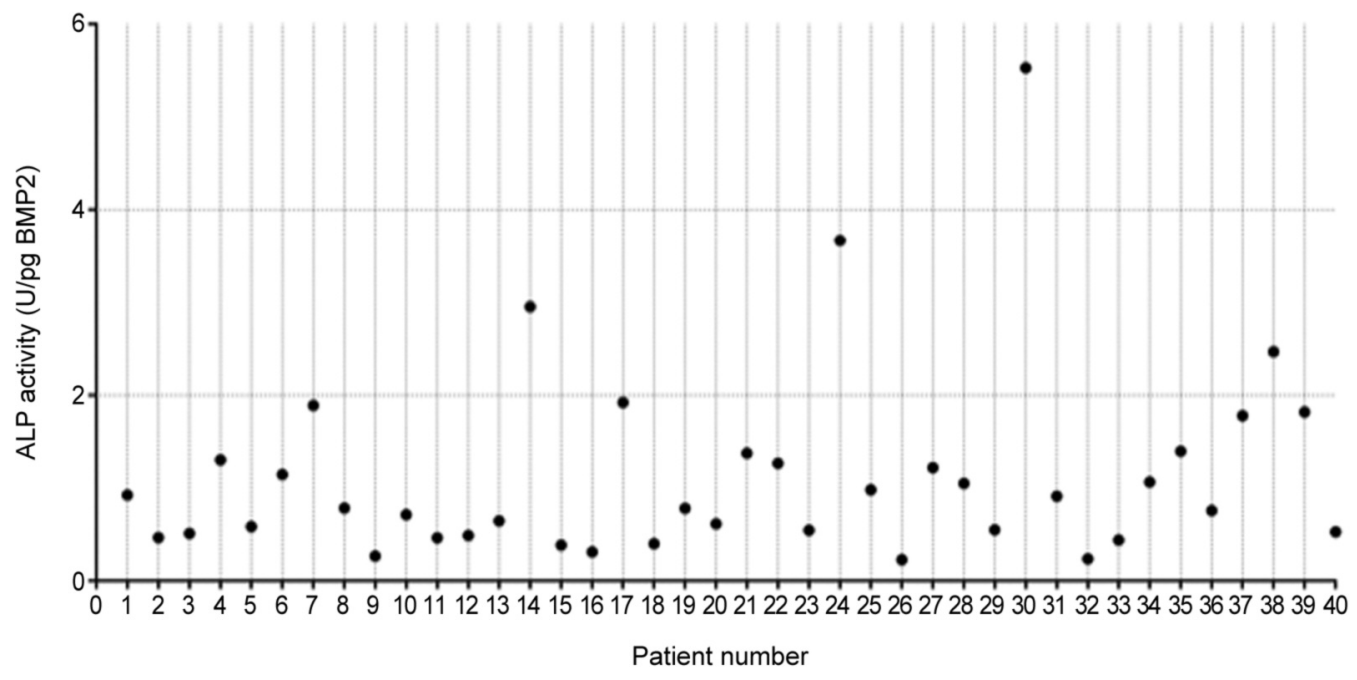

Figure 5. Activity of alkaline phosphatase (ALP) by bone morphogenetic protein 2 (BMP2) per 50 ul sample of bone extract for each patient.
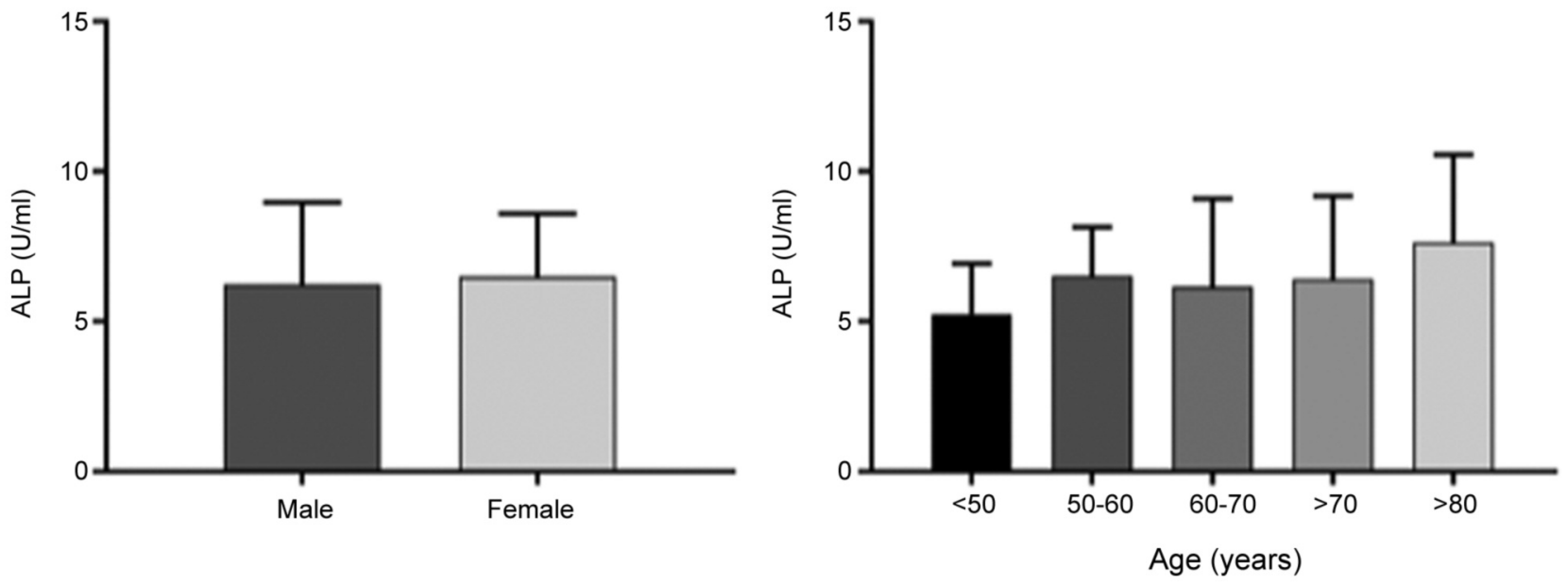

Figure 6. Activity of alkaline phosphatase (ALP) by bone morphogenetic protein 2 (BMP2) per $50 \mu$ sample of bone extract by gender (A) and by age (B). Data values are reported as the mean \pm SEM.

complete extraction. The authors did not differentiate by gender or age in their study (30). As far as we are aware to date, no studies have shown the relationship between a patient's age and the amount of the BMPs in bone allografts.

The amount of BMP2 was found to vary significantly between patients, and somewhat by age and gender. In this study, the amount of BMP2 was higher in patients from 6070 years old in comparison with the younger patients. However, patients older than 70 years showed a reduced amount of BMP2 in comparison with patients from 60-70 years of age. Although the amount of BMP2 was higher in the patients with 60-70 years old, the activity of the protein was lowest in patients of this group. The group of patients with 50-60 years of age showed the highest activity of BMP2. This information shows that the osteogenic potential of different bone grafts samples is not consistent.

In this study the amount and activity of BMP2 in femur heads obtained from patients undergoing total hip replacement surgery varied do a degree according to gender and age. The use of bone proteins as markers for tissue quality in bone banks might be promising and should be further investigated.

\section{Conflicts of Interest}

The Authors declare that there are no conflicts of interest. 


\section{Authors' Contributions}

A. Wurm: Study protocol, study design, literature research, data analysis, editing and writing of the article. D. Dammerer: Literature research, data analysis, editing, writing and proofreading of the article. M. Liebensteiner: Co-editing, proofreading of the article. M. Nogler: Data analysis and proofreading of the article. C. Ammann: supervised the study results and proofread the article. C. CoraçaHuber: Study protocol, study design, literature research, data analysis, editing and writing of the article. All Authors made pertinent contributions to the article, and proofread and approved the final article before submission.

\section{References}

1 Nodzo SR, Boyle KK, Pavlesen S and Rachala S: Bone morphogenic protein-2 use in revision total hip arthroplasty with acetabular defects. Int Orthop 42(4): 783-789, 2018. PMID: 29098380. DOI: 10.1007/s00264-017-3671-3

2 Coraca-Huber DC, Hausdorfer J, Fille M and Nogler M: Effect of storage temperature on gentamicin release from antibioticcoated bone chips. Cell Tissue Bank 14(3): 395-400, 2013. PMID: 22936498. DOI:10.1007/s10561-012-9339-8

3 Hinsenkamp M, Muylle L, Eastlund T, Fehily D, Noel L and Strong DM: Adverse reactions and events related to musculoskeletal allografts: Reviewed by the World Health Organisation project Notify. Int Orthop 36(3): 633-641, 2012. PMID: 22048753. DOI: 10.1007/s00264-011-1391-7

4 Lewis CS, Katz J, Baker MI, Supronowicz PR, Gill E and Cobb RR: Local antibiotic delivery with bovine cancellous chips. J Biomater Appl 26(4): 491-506, 2011. PMID: 20819915. DOI: $10.1177 / 0885328210375729$

5 Sommerfeldt DW, Linhart W, Schmandra TC, Konold P and Rueger JM: Die knochenbank richtlinien - probleme anwendung. Unfallchirurgie 24(5): 236-244, 1998. DOI: 10.1007/ BF02428390

6 Gonzaga MG, Dos Santos Kotake BG, de Figueiredo FAT, Feldman S, Ervolino E, Dos Santos MCG and Issa JPM: Effectiveness of rhBMP2 association to autogenous, allogeneic, and heterologous bone grafts. Microsc Res Tech 82(6): 689-695, 2019. PMID: 30637849. DOI: 10.1002/jemt.23215

7 Verordnung der Bundesministerin fuer Gesundheit, Familie und Jugend, mit der naehere Regelungen fuer den Betrieb von Gewebebanken getroffen werden (GewebebankenverordenungGBVO), GBVO, 2013.

8 Verordnung der Bundesministerin fuer Gesundheit, Familie und Jugend zur Festlegung von Standards fuer die Gewinnung von zur Verwendung beim Menschen bestimmter menschlicher Zellen und Geweben (Gewebeentnahmeeinrichtungsverordnung - GEEVO), GEEVO, 2013.

9 Bundesgesetz ueber die Festlegung von Qualitaets- und Sicherheitsstandards fuer die Gewinnung, Verarbeitung, Lagerung und Verteilung von menschlichen Zellen und Geweben zur Verwendung beim Menschen (GewebesicherheitsgesetzGSG), BGB1.II Nr. 49/2008 GSG, 2013.

10 Zwitser EW, Jiya TU, George Licher H and van Royen BJ: Design and management of an orthopaedic bone bank in the Netherlands. Cell Tissue Bank 13(1): 63-69, 2012. PMID: 21076877. DOI: $10.1007 / \mathrm{s} 10561-010-9230-4$
11 de Alencar PGC and Vieira IFV: Bone banks. Rev Bras Ortop 45(6): 524-528, 2010. PMID: 27026958. DOI: 10.1016/S22554971(15)30297-4

12 Nather A: Musculoskeletal tissue banking in Singapore: 15 Years of experience (1988-2003). J Orthop Surg 12(2): 184-190, 2004. PMID: 15621904. DOI: 10.1177/230949900401200209

13 Chen G, Deng C and Li YP: TGF-beta and BMP signaling in osteoblast differentiation and bone formation. Int J Biol Sci 8(2): 272-288, 2012. PMID: 22298955. DOI: 10.7150/ijbs.2929

14 Kumar V, Abbas AK, Fausto N and Aster JC: Tissue renewal, regeneration, and repair. In: Robbins and Cotran Pathologic Basis of Disease Eighth Edition. Kumar V, Abbas AK, Fausto N and Aster JC (eds.). Saunders Elsevier: Philadelphia, PA, pp. 1450, 2010.

15 Belfrage O, Flivik G, Sundberg M, Kesteris U and Tagil M: Local treatment of cancellous bone grafts with BMP-7 and zoledronate increases both the bone formation rate and bone density: A bone chamber study in rats. Acta Orthop 82(2): 228233, 2011. PMID: 21434769. DOI: 10.3109/17453674. 2011.566138

16 Maurer T, Zimmermann G, Maurer S, Stegmaier S, Wagner C and Hansch GM: Inhibition of osteoclast generation: A novel function of the bone morphogenetic protein 7/osteogenic protein 1. Mediators Inflamm 2012: 171209, 2012. PMID: 23132958. DOI: $10.1155 / 2012 / 171209$

17 Ai-Aql ZS, Alagl AS, Graves DT, Gerstenfeld LC and Einhorn TA: Molecular mechanisms controlling bone formation during fracture healing and distraction osteogenesis. J Dent Res 87(2): 107-118, 2008. PMID: 18218835. DOI: 10.1177/ 154405910808700215

18 Lissenberg-Thunnissen SN, de Gorter DJ, Sier CF and Schipper IB: Use and efficacy of bone morphogenetic proteins in fracture healing. Int Orthop 35(9): 1271-1280, 2011. PMID: 21698428. DOI: $10.1007 / \mathrm{s} 00264-011-1301-\mathrm{z}$

19 Hara Y, Ghazizadeh M, Shimizu H, Matsumoto H, Saito N, Yagi T, Mashiko K, Mashiko K, Kawai M and Yokota H: Delayed expression of circulating TGF $\beta 1$ and BMP2 levels in human nonunion long bone fracture healing. J Nippon Med Sch 84(1): 12-18, 2017. PMID: 28331138. DOI: $10.1272 /$ jnms.84.12

20 Jones AL: Recombinant human bone morphogenic protein-2 in fracture care. J Orthop Trauma 19(10 Suppl): S23-25, 2005. PMID: 16479219. DOI: 10.1097/00005131-200511101-00007

21 Aro HT, Govender S, Patel AD, Hernigou P, Perera de Gregorio A, Popescu GI, Golden JD, Christensen J and Valentin A: Recombinant human bone morphogenetic protein-2: A randomized trial in open tibial fractures treated with reamed nail fixation. J Bone Joint Surg Am 93(9): 801-808, 2011. PMID: 21454742. DOI: $10.2106 / J B J S . I .01763$

22 Szczesny G, Olszewski WL, Zagozda M, Rutkowska J, Czapnik Z, Swoboda-Kopec E and Gorecki A: Genetic factors responsible for long bone fractures non-union. Arch Orthop Trauma Surg 131(2): 275-281, 2011. PMID: 20730440. DOI: 10.1007/s00402-010-1171-7

23 Tsuji K, Bandyopadhyay A, Harfe BD, Cox K, Kakar S, Gerstenfeld L, Einhorn T, Tabin CJ and Rosen V: BMP2 activity, although dispensable for bone formation, is required for the initiation of fracture healing. Nat Genet 38(12): 1424-1429, 2006. PMID: 17099713. DOI: $10.1038 / n g 1916$

24 Wurm A, Nogler M, Ammann CG and Coraca-Huber DC: Effect of storage temperature and antibiotic impregnation on the 
quantity of bone morphogenetic protein seven in human bone grafts. Int Orthop 38(7): 1513-1517, 2014. PMID: 24806532. DOI: $10.1007 / \mathrm{s} 00264-014-2349-3$

25 Takata M, Sugimoto N, Yamamoto N, Shirai T, Hayashi K, Nishida H, Tanzawa Y, Kimura H, Miwa S, Takeuchi A and Tsuchiya H: Activity of bone morphogenetic protein-7 after treatment at various temperatures: Freezing vs. pasteurization $v s$. allograft. Cryobiology 63(3): 235-239, 2011. PMID: 21963423. DOI: 10.1016/j.cryobiol.2011.09.001

26 Wurm A, Steiger R, Ammann CG, Putzer D, Liebensteiner MC, Nogler $M$ and Coraca-Huber DC: Changes in the chemical quality of bone grafts during clinical preparation detected by Raman spectroscopy. Biopreserv Biobank 14(4): 319-323, 2016. PMID: 27028037. DOI: 10.1089/bio.2015.0097

27 Klatte-Schulz F, Pauly S, Scheibel M, Greiner S, Gerhardt C, Hartwig J, Schmidmaier G and Wildemann B: Characteristics and stimulation potential with BMP2 and BMP-7 of tenocytelike cells isolated from the rotator cuff of female donors. PLoS One 8(6): e67209, 2013. PMID: 23825642. DOI: 10.1371/ journal.pone.0067209
28 Majidinia M, Sadeghpour A and Yousefi B: The roles of signaling pathways in bone repair and regeneration. J Cell Physiol 233(4): 2937-2948, 2018. PMID: 28590066. DOI: $10.1002 /$ jcp. 26042

29 Muller CW, Hildebrandt K, Gerich T, Krettek C, van Griensven $\mathrm{M}$ and Rosado Balmayor E: BMP2-transduced human bone marrow stem cells enhance neo-bone formation in a rat criticalsized femur defect. J Tissue Eng Regen Med 11(4): 1122-1131, 2017. PMID: 25783748. DOI: 10.1002/term.2015

30 Wildemann B, Kadow-Romacker A, Pruss A, Haas NP and Schmidmaier G: Quantification of growth factors in allogenic bone grafts extracted with three different methods. Cell Tissue Bank 8(2): 107-114, 2007. PMID: 17063261. DOI: 10.1007/ s10561-006-9021-0
Received November 8, 2020

Revised November 26, 2020

Accepted December 4, 2020 